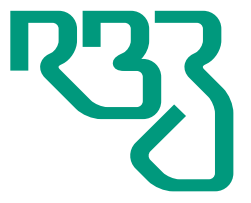

Revista Brasileira de Zootecnia

Brazilian Journal of Animal Science ISSN 1806-9290 www.rbz.org.br

\section{Feeding rate and feeding frequency affect growth performance of common snook (Centropomus undecimalis) juveniles reared in the laboratory}

\author{
Ricardo Luís Mendes de Oliveira' ${ }^{1,2}$ (iD), Leilane Bruna Gomes dos Santos ${ }^{1,3}$ (iD), \\ Nelson Gomes da Silva Neto $^{1}$ iD, , Scarlatt Paloma Alves da Silva ${ }^{1}$ (iD), \\ Felipe dos Santos Silva ${ }^{1}$ (iD), Enrique Melatti ${ }^{1}$ (iD), Ronaldo Olivera Cavalli ${ }^{1,4^{*}}$ iD \\ ${ }^{1}$ Universidade Federal Rural de Pernambuco, Departamento de Pesca e Aquicultura, Recife, \\ PE, Brasil. \\ ${ }^{2}$ Instituto Federal de Educação, Ciência e Tecnologia da Paraíba, Campus Cabedelo, \\ Cabedelo, PB, Brasil. \\ ${ }^{3}$ Instituto Federal de Educação, Ciência e Tecnologia do Espírito Santo, Campus Piúma, \\ Piúma, ES, Brasil. \\ ${ }^{4}$ Universidade Federal do Rio Grande, Instituto de Oceanografia, Rio Grande, RS, Brasil.
}

*Corresponding author: ronaldocavalli@gmail.com

Received: November 10, 2017

Accepted: August 20, 2018

How to cite: Oliveira, R. L. M.; Santos, L. B. G.; Silva Neto, N. G.; Silva, S. P. A.; Silva, F. S.; Melatti, E. and Cavalli, R. O. 2019. Feeding rate and feeding frequency affect growth performance of common snook (Centropomus undecimalis) juveniles reared in the laboratory. Revista Brasileira de Zootecnia 48:e20170292. https://doi.org/10.1590/rbz4820170292

Copyright: This is an open access article distributed under the terms of the Creative Commons Attribution License (http://creativecommons.org/licenses/by/4.0/) which permits unrestricted use, distribution, and reproduction in any medium, provided the original work is properly cited.

\begin{abstract}
The effects of feeding rate and feeding frequency on the growth of laboratory-reared common snook (Centropomus undecimalis) were evaluated. Juveniles with mean \pm SD weight of $2.55 \pm 0.48 \mathrm{~g}$ and total length of $6.81 \pm 0.48 \mathrm{~cm}$ were divided into groups of 20 fish and reared in 30 polyethylene tanks of $50 \mathrm{~L}$ for 60 days. The experimental design was a $3 \times 3$ factorial with three feeding frequencies (F2, F4, and F6: two, four, and six daily meals, respectively), three feeding rates (R1, R2.5, and R4: $1.0,2.5$, and $4.0 \%$ /day of fish biomass, respectively), and three replicates, totaling nine treatments (F2R1, F2R2.5, F2R4; F4R1, F4R2.5, F4R4; F6R1, F6R2.5, and F6R4). The external control consisted of four meals a day offered to apparent satiety (F4S). Every 15 days, weight and length of all fish were measured to adjust the amount of feed offered. Water quality variables remained within adequate levels for this species. Feeding rate had a greater influence on performance than frequency. Survival, condition factor, and the initial and final coefficients of weight variation had no significant effect among treatments. Feeding frequency and rate directly influenced length and weight gains, feed efficiency, specific growth rate, and apparent feed conversion rate. For common snook juveniles weighing between 1 and $16 \mathrm{~g}$, it is recommended to offer four to six daily meals at a feeding rate between 3.31 and $1.86 \%$ per day, which should decrease according to fish size.
\end{abstract}

Keywords: aquaculture, feeding, feed management, marine fish farming

\title{
Introduction
}

Among the various species with potential to leverage marine fish farming in Brazil, the snook of the genus Centropomus (C. undecimalis and C. parallelus) stand out with relatively fast growth, good feed conversion, and possibility of being reared in relatively high densities (Alvarez-Lajonchère and Tsuzuki, 2008). However, common snook shows faster growth than fat snook (C. parallelus) (Alvarez-Lajonchère, 2004), being more suitable for aquaculture. Common snook has high commercial value (US\$10.00/kg; CEAGESP, 2016), inhabits coastal and estuarine waters from Florida, USA, to Santa Catarina, Brazil 
(Rivas, 1986), and reaches over $1.0 \mathrm{~m}$ and $20.0 \mathrm{~kg}$ (Figueiredo and Menezes, 1980). In nature, it feeds mainly on fish and crustaceans, presenting carnivorous feeding habits (Alvarez-Lajonchère, 2004).

It is estimated that feed costs represent about $45 \%$ of operating costs in the semi-intensive farming of common snook (Sanches et al., 2014). Considering the importance of the diet on fish performance, feed management must be optimized to reduce costs (Türkmen et al., 2012), enhance growth, survival, feed conversion, reduce batch size heterogeneity, and minimize the release of waste into the environment (Goddard, 1996; Kubitza and Lovshin, 1999; Xie et al., 2011). However, even with the potential to reduce economic and environmental pressures, relatively few studies have established adequate feeding management practices for marine fish (Costa-Bomfim et al., 2014).

Feeding frequency and rate influence the development of several fish species (Biswas et al., 2010; Corrêa et al., 2010; Barbosa et al., 2011; Costa-Bomfim et al., 2014; Tsuzuki et al., 2014). These aspects have been widely studied in the Asian sea bass (Lates calcarifer) and European sea bass (Dicentrarchus labrax) (Azzaydi et al., 1998; Eroldoğan et al., 2004; Harpaz et al., 2005; Guroy et al., 2006; Salama, 2008; Biswas et al., 2010; Türkmen et al., 2012; Ribeiro et al., 2015). For C. parallelus, however, so far, studies have only considered feeding frequency (Tsuzuki and Berestinas, 2008; Corrêa et al., 2010; Tsuzuki et al., 2014) and rate (Barbosa et al., 2011; Oliveira et al., 2013) separately. Regarding C. undecimalis, only a single study evaluating feeding frequency is available (García-Galano et al., 2003). Therefore, this study evaluated the effects of different sets of feeding frequencies and rates on growth performance of laboratory-reared common snook juveniles.

\section{Material and Methods}

The experimental work was conducted in Recife, PE, Brazil (08 $01^{\prime} 11^{\prime \prime} \mathrm{S}$ and $\left.034^{\circ} 56^{\prime} 38^{\prime \prime} \mathrm{W}\right)$. Research on animals was conducted according to the institutional committee on animal use (case no. 171).

Groups of 20 laboratory-reared common snook juveniles with $2.55 \pm 0.48 \mathrm{~g}$ and $6.81 \pm 0.48 \mathrm{~cm}$ in weight and total length, respectively, were stocked into thirty 50-L polyethylene tanks in a recirculation system. Initial stocking density was $3.06 \pm 0.06 \mathrm{~g} \cdot \mathrm{L}^{-1}$. Temperature $\left({ }^{\circ} \mathrm{C}\right)$, salinity, dissolved oxygen $(\mathrm{mg} / \mathrm{L})$, and pH were measured daily with a multi-parameter model YSI 556 (Yellow Springs Instruments, USA) and a benchtop pH meter model PHS-3BW (Bel Engineering, Brazil). The concentrations of total ammonia, nitrite, and nitrate were determined three times a week with a photometer model YSI 9500 (Yellow Springs Instruments, USA). The photoperiod cycle was $12 \mathrm{~h}$ light:12 h dark throughout the study. The water quality variables remained within levels deemed acceptable for common snook: salinity 20.3 \pm 1.1 , temperature $30.3 \pm 0.5^{\circ} \mathrm{C}, \mathrm{pH} 8.09 \pm 0.14$, and dissolved oxygen $6.8 \pm 1.4 \mathrm{mg} / \mathrm{L}$. The mean total ammonia concentration was $0.10 \pm 0.14 \mathrm{mg} / \mathrm{L}$. No significant concentrations of nitrite and nitrate were detected.

A $3 \times 3$ factorial experimental design was utilized, including three feeding frequencies (F2, F4, and F6; two, four, and six meals per day, respectively), three feeding rates (R1, R2.5, and R4; $1.0,2.5$, and $4.0 \%$ of fish biomass, respectively), and three replicates, totaling nine treatments (F2R1, F2R2.5, F2R4; F4R1, F4R2.5, F4R4; F6R1, F6R2.5, F6R4). The external control consisted of four daily meals offered to apparent satiety (F4S).

All fish were fed to satiation for seven days until the beginning of the trial (acclimation period) with the same commercial, slow sinking feed $\left(550 \mathrm{~g} \cdot \mathrm{kg}^{-1}\right.$ crude protein and $100 \mathrm{~g} \cdot \mathrm{kg}^{-1}$ total lipids) used during the 60-day experimental period. The amount of feed was established according to meal times: 8:00 and 17:00 h (twice a day); 8:00, 11:00, 14:00, and 17:00 h (four times a day); and 8:00, 9:50, 11:40, 13:30, 15:20, and 17:00 h (six times a day).

Every 15 days, all individuals of each tank were anesthetized with a clove oil solution (AQUI-S, Bayer S.A., Chile), individually weighed on a digital scale (model S 622 Bel Engineering, Brazil; e $=0.1 \mathrm{~g}$ ), and measured (total length; $\mathrm{cm}$ ). The mean values of weight ( $\mathrm{g}$ ) were used for the correction of the feeding rates.

R. Bras. Zootec., 48:e20170292, 2019 
Survival rate (S), total length (LG) and weight gains (WG), apparent feed conversion rate (FCR), specific growth rate (SGR), feed efficiency (FE), condition factor (K), and the initial (ICV) and final (FCV) coefficients of weight variation were estimated as follows:

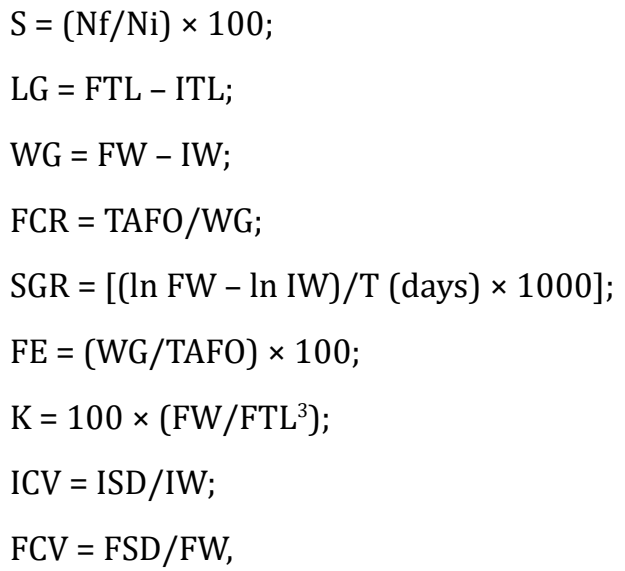

in which $\mathrm{Nf}$ is the number of fish at the end of the trial, $\mathrm{Ni}$ is the number of fish initially stocked, LG is the total length gain, FTL is the final total length, ITL is the initial total length, FW is the final weight, IW is the initial weight, TAFO is the total amount of feed offered, ISD is the standard deviation of the initial weight, and FSD is the standard deviation of the final weight.

The results were assessed by analysis of variance (ANOVA) with two factors (feeding frequency and rate) and a significance level of 0.05 . The results showing significant differences were then subjected to Tukey's test $(\mathrm{P}<0.05)$.

The growth curve (in terms of weight) in relation to the feeding rate was adjusted to a polynomial regression of the second order: $y=a^{2}+b x+c$, in which $x$ is the feeding rate, $c$ is the intersection of the curve, and $a$ and $b$ are regression coefficients. From this curve, we estimated the maximum (Rmax), maintenance (Rmain), and optimal (Ro) feeding rates. Rmax was the derivative of the polynomial function $(-b / 2 a)$ as the point at which there is no increase in the analyzed parameter (Shearer, 2000), while the maintenance (Rmain) and optimal (Ro) feeding rates correspond to the points where the weight gain of fish is zero $\left(a x^{2}+b x+c=0\right)$ and the feed is more efficiently used $(\sqrt{c / a})$, respectively (Brett, 1979). The software R, version 3.0.2, was used to build the mathematical model and to estimate the weight ( $\mathrm{g}$ ) of fish. The input order of the variables was selected according to the Akaike criteria (AIC).

\section{Results}

No significant effect of the interaction between feeding frequency and rate was observed. Therefore, a one-way ANOVA was applied. Both the feeding frequency and rate significantly (one-way ANOVA, P-values) affected WG $(0.00 ; 0.048), \mathrm{LG}(0.00 ; 0.009)$, FCR $(0.00 ; 0.011)$, FE $(0.00 ; 0.033)$, and SGR $(0.00$; 0.020 ), respectively. On the other hand, there were no significant differences for S, K, ICV, and FCV (Table 1).

Fish fed at 2.5 and $4 \%$ of their biomass had significantly higher WG and LG, regardless of feeding frequency (Table 1). Apparent feed conversion ratio was significantly lower for fish fed at either 1 or $2.5 \%$ of their biomass, regardless of feeding frequency. The highest feeding rate ( $4 \%$ of the biomass) resulted in a significantly lower feeding efficiency (FE) (Table 1). For a given feeding frequency, there was a trend towards decreased FE with increasing feeding rates. Significantly lower SGR was observed in fish fed at $1 \%$ of the biomass, regardless of feeding rate (Table 1). Due to differences in growth between treatments, the mean final stocking density ranged from $4.65 \mathrm{~g} . \mathrm{L}^{-1}$, in treatment F2R1, to $9.44 \mathrm{~g} . \mathrm{L}^{-1}$, in F6R4. The control treatment (F4S) had a mean final density of $8.63 \mathrm{~g} \cdot \mathrm{L}^{-1}$. Overall, final stocking density was 7.50 $\pm 1.96 \mathrm{~g} . \mathrm{L}^{-1}$.

The growth curve $\left(y=-0.6987 x^{2}+4.6188 x-2.4235 ; R^{2}=0.8321\right)$ (Figure 1$)$ indicates that Rmain, Ro, and Rmax would be $0.93,1.86$, and $3.31 \%$, respectively. There was a trend towards an increase in WG in all treatments as feeding frequency and rate increased (Figure 2).

R. Bras. Zootec., 48:e20170292, 2019 
Table 1 - Growth performance and feed utilization of common snook (Centropomus undecimalis) juveniles fed at different feeding frequency and feeding rates

\begin{tabular}{lccccccccc}
\hline & $\mathrm{S}$ & $\mathrm{WG}$ & $\mathrm{LG}$ & $\mathrm{FCR}$ & $\mathrm{K}$ & $\mathrm{FE}$ & $\mathrm{SGR}$ & $\mathrm{ICV}$ & FCV \\
\hline F2R1 & 98.3 & $1.3 \mathrm{a}$ & $1.4 \mathrm{a}$ & 1.3 & 7.0 & $78.8 \mathrm{~b}$ & $0.7 \mathrm{a}$ & 18.1 & 21.3 \\
& $(2.9)$ & $(0.1)$ & $(0.1)$ & $(0.1) \mathrm{a}$ & $(0.3)$ & $(3.7)$ & $(0.0)$ & $(2.6)$ & $(5.2)$ \\
F2R2.5 & 98.3 & $4.6 \mathrm{~b}$ & $3.0 \mathrm{bc}$ & 1.4 & 7.4 & $75.1 \mathrm{~b}$ & $1.8 \mathrm{~b}$ & 18.6 & 24.8 \\
& $(2.9)$ & $(1.4)$ & $(0.4)$ & $(0.3) \mathrm{a}$ & $(0.4)$ & $(17.5)$ & $(0.3)$ & $(1.0)$ & $(5.2)$ \\
F2R4 & 100.0 & $3.8 \mathrm{~b}$ & $2.8 \mathrm{~b}$ & 2.4 & 7.2 & $41.2 \mathrm{a}$ & $1.7 \mathrm{~b}$ & 18.4 & 20.3 \\
& $(0.0)$ & $(0.6)$ & $(0.2)$ & $(0.2) \mathrm{b}$ & $(0.2)$ & $(3.6)$ & $(0.2)$ & $(0.4)$ & $(4.5)$ \\
F4R1 & 96.7 & $1.5 \mathrm{a}$ & $1.5 \mathrm{a}$ & 1.2 & 7.0 & $83.7 \mathrm{bc}$ & $0.8 \mathrm{a}$ & 19.2 & 14.8 \\
& $(5.8)$ & $(0.1)$ & $(0.1)$ & $(0.0) \mathrm{a}$ & $(0.2)$ & $(2.7)$ & $(0.0)$ & $(1.3)$ & $(4.2)$ \\
F4R2.5 & 96.7 & $4.8 \mathrm{~b}$ & $3.2 \mathrm{bc}$ & 1.3 & 7.4 & $74.7 \mathrm{~b}$ & $1.9 \mathrm{~b}$ & 16.1 & 25.1 \\
& $(2.9)$ & $(0.3)$ & $(0.2)$ & $(0.1) \mathrm{a}$ & $(0.3)$ & $(3.4)$ & $(0.1)$ & $(2.8)$ & $(1.9)$ \\
F4R4 & 100.0 & $5.2 \mathrm{~b}$ & $3.5 \mathrm{bc}$ & 2.1 & 7.2 & $48.8 \mathrm{a}$ & $2.0 \mathrm{~b}$ & 18.2 & 22.0 \\
& $(0.0)$ & $(0.1)$ & $(0.1)$ & $(0.1) \mathrm{b}$ & $(0.0)$ & $(2.5)$ & $(0.1)$ & $(2.2)$ & $(0.6)$ \\
F6R1 & 98.3 & $1.7 \mathrm{a}$ & $1.6 \mathrm{a}$ & 1.0 & 7.2 & $99.3 \mathrm{c}$ & $0.9 \mathrm{a}$ & 20.9 & 16.2 \\
& $(2.9)$ & $(0.1)$ & $(0.1)$ & $(0.1) \mathrm{a}$ & $(0.2)$ & $(7.6)$ & $(0.1)$ & $(2.3)$ & $(2.0)$ \\
F6R2.5 & 100.0 & $5.0 \mathrm{~b}$ & $3.2 \mathrm{bc}$ & 1.3 & 7.4 & $78.9 \mathrm{bc}$ & $1.9 \mathrm{~b}$ & 20.3 & 27.2 \\
& $(0.0)$ & $(1.2)$ & $(0.4)$ & $(0.2) \mathrm{a}$ & $(0.2)$ & $(11.2)$ & $(0.2)$ & $(2.0)$ & $(5.3)$ \\
F6R4 & 96.7 & $5.6 \mathrm{~b}$ & $3.5 \mathrm{c}$ & 2.1 & 7.4 & $48.5 \mathrm{a}$ & $2.1 \mathrm{~b}$ & 20.5 & 21.9 \\
& $(5.8)$ & $(0.4)$ & $(0.1)$ & $(0.1) \mathrm{b}$ & $(0.2)$ & $(3.5)$ & $(0.1)$ & $(1.4)$ & $(5.5)$ \\
F4S & 100.0 & $4.6 \mathrm{~b}$ & $3.1 \mathrm{bc}$ & 1.0 & 7.3 & $97.5 \mathrm{bc}$ & $1.8 \mathrm{~b}$ & 17.7 & 24.2 \\
& $(0.0)$ & $(0.4)$ & $(0.2)$ & $(0.0) \mathrm{a}$ & $(0.2)$ & $(1.7)$ & $(0.1)$ & $(3.3)$ & $(5.9)$ \\
\hline
\end{tabular}

S - survival; WG - weight gain; LG - total length gain; FCR - apparent feed conversion rate; K - condition factor; FE - feed efficiency; SGR - specific growth rate; ICV - initial coefficient of variation of weight; FCV - final coefficient of variation of weight.

F2, F4, and F6: two, four, and six meals per day, respectively; R1, R2.5, and R4: 1.0, 2.5, and 4.0\% of fish biomass, respectively;

F4S: external control consisted of four daily meals offered to apparent satiety.

Different letters within the same column indicate significant differences $(\mathrm{P}<0.05)$

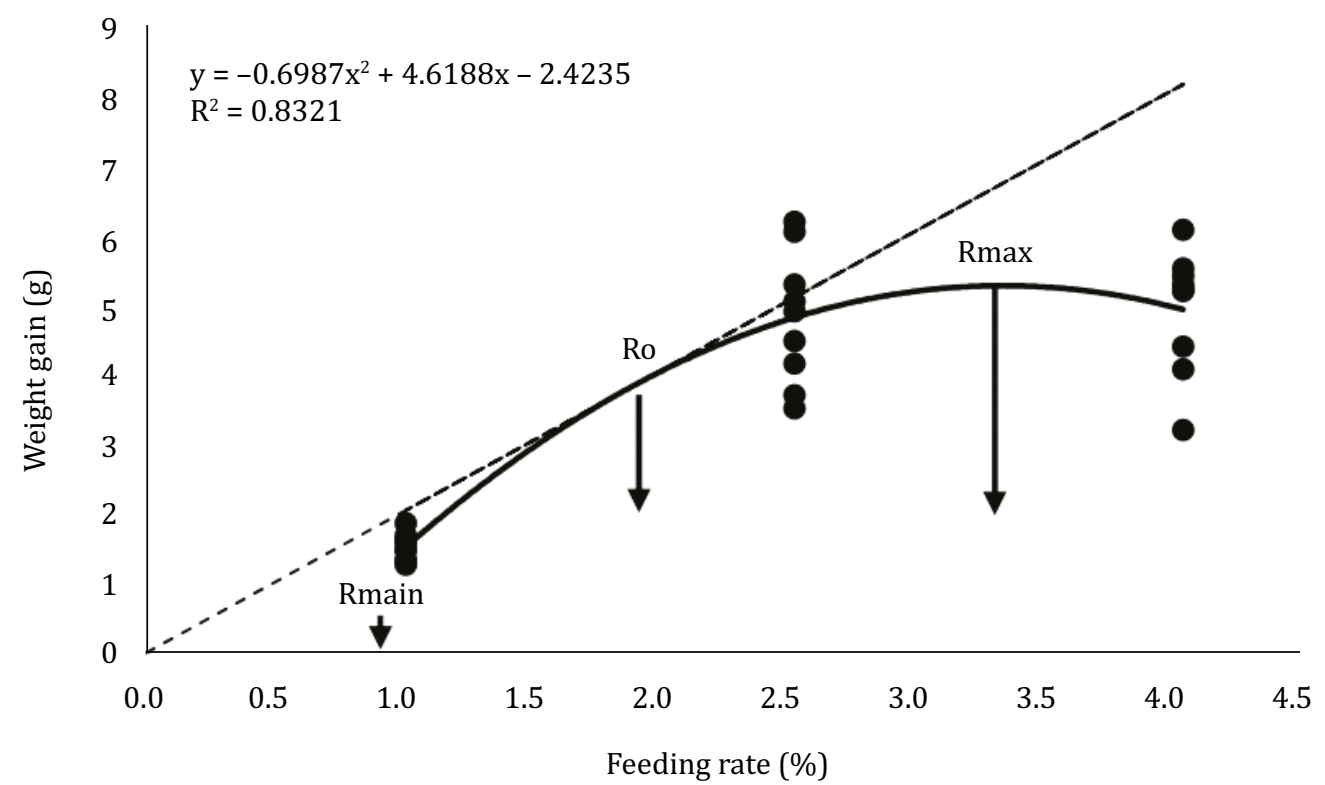

The curve represents the second order polynomial regression adjusted to the data, as follows: $y=$ feeding rate, $\mathrm{x}=$ weight gain, and the coefficients are constants determined by the regression.

The maintenance (Rmain), optimal (Ro), and maximum (Rmax) rates were estimated at $0.93,1.86$, and 3.31\%, respectively.

Figure 1 - Weight gain (g) of common snook (Centropomus undecimalis) juveniles fed at different feeding rates $(1,2.5$, and $4 \%$ of fish biomass) for 60 days. 


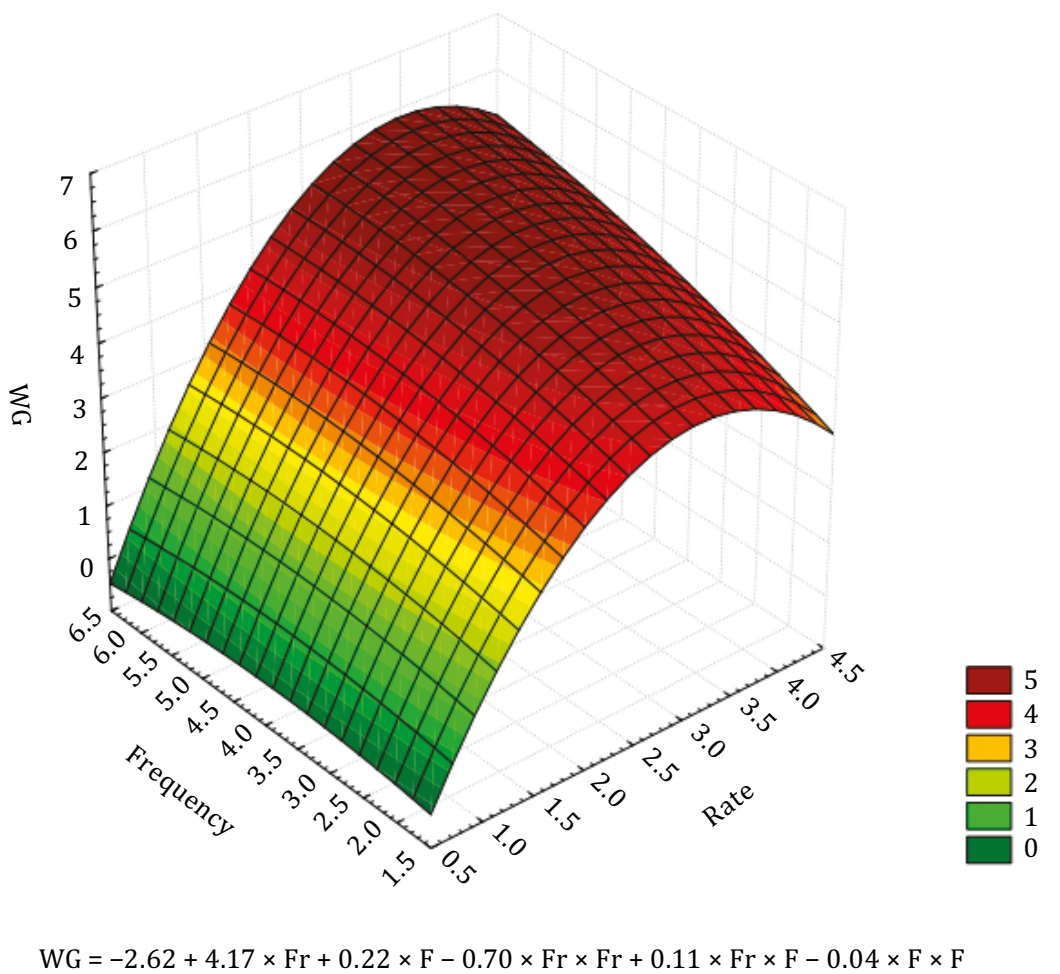

Fr - feeding rate (percentage of feed offered per day in relation to fish biomass); $\mathrm{F}$ - feeding frequency (number of daily meals).

Figure 2 - Weight gain (WG; g) of common snook (Centropomus undecimalis) juveniles fed at three feeding frequencies and three feeding rates for 60 days.

Feeding the fish to satiation (F4S treatment) allowed the estimation of the average feeding rate throughout the trial, which decreased according to fish weight. The initial rate was $3.15 \%$ of fish biomass, but reached $0.95 \%$ of the total biomass at day 60 . For the whole period, the mean rate was estimated at $2.1 \%$. For the same treatment, variations in feed intake were observed according to the daily feeding schedule. The average amount of feed consumed during the experimental period was higher at 8:00 $\mathrm{h}(0.49 \pm 0.27 \mathrm{~g})$, decreasing successively at the following times $(11: 00 \mathrm{~h}$ : $0.42 \pm 0.23 \mathrm{~g}$; and $14: 00 \mathrm{~h}: 0.40 \pm 0.21 \mathrm{~g}$ ). The lowest feed intake was observed in the last feeding at $17: 00 \mathrm{~h}(0.34 \pm 0.20 \mathrm{~g})$.

The weight (W; $\mathrm{g}$ ) of fish over time, depending on the different feeding frequencies and rates, presented means between 1.4 and $15.8 \mathrm{~g}$. It was estimated by a linear model $\left(\mathrm{R}^{2}=0.61\right)$ :

$$
\mathrm{W}=0.69+0.07 \times \mathrm{T}+0.96 \times \mathrm{Fr}-0.06 \times \mathrm{F},
$$

in which $\mathrm{T}$ is time (days), Fr is the feeding rate (daily percentage of feed offered), and $\mathrm{F}$ is the feeding frequency (number of meals per day).

\section{Discussion}

Common snook juveniles fed at the lowest feeding rate (1\% of biomass) showed significantly slower growth (lower WG and LG) from day 15 onwards, regardless of feeding frequency. This may be a consequence of a low feed offer. Combining increased feeding frequencies and rates resulted in higher WG and LG, which agrees with Tsuzuki et al. (2014), who verified the influence of feeding frequency on the growth of $C$. parallelus juveniles, and García-Galano et al. (2003), who observed higher weight gains in $C$. undecimalis fed at higher frequencies. On the other hand, Corrêa et al. (2010) reported that feeding frequency had no effect on the performance of $C$. parallelus juveniles fed at a rate of $6 \%$ of their biomass. Barbosa et al. (2011) argued that feeding rates below the level considered optimal may 
lead to increased batch size heterogeneity, possibly due to competition for food. However, this was not observed in this study, since the size of fish from all treatments remained homogeneous throughout the experimental period.

Despite the slower growth, the high survival and lack of aggressive interactions between fish indicate the non-occurrence of cannibalism, which is commonly observed in this species (Tucker, 1987; Cerqueira and Tsuzuki, 2009; Corrêa and Cerqueira, 2007, 2008). For the Asian sea bass (L. calcarifer), cannibalism may be reduced or delayed by using high feeding frequencies, contributing to batch size homogeneity (Ribeiro et al., 2015). Similarly, using daily feeding rates between 1 and $6 \%$ for C. parallelus also resulted in high survival (Barbosa et al., 2011; Oliveira et al., 2013).

Estimates of Rmain, Ro, and Rmax in this study $(0.93,1.86$, and $3.31 \%$, respectively) were higher than reported for C. parallelus $(0.53,1.7$, and $3 \%$, respectively) by Barbosa et al. (2011). Fish from that study, however, were larger (30 g). Eroldoğan et al. (2004) estimated Rmain, Ro, and Rmax of the European sea bass (D. labrax) with an initial weight similar to our study at $0.6,2.5$, and $5.2 \%$ for those reared in sea water, and $0.9,3.0$, and $5.7 \%$ for fish reared in freshwater. In addition to the differences in fish size between studies, the differences among these rates may also be a result of the higher growth rate of D. labrax compared to $C$. undecimalis, whereas $C$. parallelus has a comparatively lower growth compared with the common snook (Tucker, 2000; Tsuzuki et al., 2008).

In general, a greater stratification of the results was more often observed in relation to feeding rates than for feeding frequency. This is clear when observing the mathematical model, in which the coefficient accompanying the variable "feeding rate" is numerically higher (0.96) than that accompanying the variable "frequency" $(-0.06)$. A similar fact was observed for parameters such as WG, FCR, SGR, and LG.

The combination of comparatively higher feeding frequencies and rates resulted in increased feed intake, more efficient feed use, and improved growth performance. This is case, for instance, of snook fed at rates of 2.5 and $4 \%$ combined with frequencies of four and six meals per day. Fish fed more often consume more feed when compared with those fed less frequently (Dwyer et al., 2002). In aquaculture, feeding frequency generally varies according to fish size; small fish are fed more frequently than larger ones (Biswas et al., 2010). The increased frequency enables that fish reared at higher densities have greater access to feed due to its better distribution, leading to higher weight gain (Tsuzuki et al., 2014). However, fish from the treatment F2R4 did not consume all the feed supplied from day 28 onwards, even with biological indexes similar to fish fed at the same rate. Since Rmax was estimated at $3.31 \%$, a feed waste of $0.69 \%$ per day, therefore, can be estimated. Bendhack et al. (2013) verified that C. parallelus juveniles consumed feed in the bottom of the tanks after apparent satiation. In our study, however, fish fed at a rate of $4 \%$ were not observed ingesting pellets that remained in the tank bottoms.

Regardless of feeding frequency, fish fed at the $4 \%$ rate had low FE and high FCR, indicating the low utilization of the supplied feed despite their comparatively higher growth. High growth rates accompanied by high feed conversion rates lead to feed waste (Barbosa et al., 2011.), which should be avoided as it increases production costs (Cho et al., 2007; Kim et al., 2007; Oliveira et al., 2013; Sanches et al., 2014) and ammonia concentrations, and may negatively affect fish growth (Oliveira et al., 2013).

On the other hand, fish fed six daily meals at a feeding rate of 1\% (treatment F6R1) had the highest FE, possibly due to the optimization of feed utilization induced by feed deprivation (Eroldoğan et al., 2004). When testing feeding rates of 1.0, 1.5, 2.0, and 2.5\%, Barbosa et al. (2011) found that C. parallelus fed at $1 \%$ rate had significantly lower FCR, which concurred in our study.

Supplying feed to satiation resulted in lower FCR and higher FE. This is mainly due to the amount of feed offered being close to what is assumed to be the ideal amount, i.e., with no food wastes observed during the trial period. The estimated amount of feed supplied to the external control treatment (F4S) was $2.1 \%$, which is close to the optimal rate of $1.86 \%$ estimated here according to the methodology 
proposed by Brett (1979). This assumption is reinforced by the fact that all the tanks containing fish fed at the $4 \%$ feeding rate had feed leftovers at the end of the day.

Regardless of treatment, K was relatively high in all treatments (7.24 \pm 0.22$)$. Generally, high K values are associated with a good condition of the individuals. The condition factor is often used in fish biology studies as an indicator of the physiological state of animals and is based in the assumption that fish with higher weight at a given length are in a better condition (Lima-Junior et al., 2002). In this study, therefore, it is understood that fish of all treatments were subjected to relatively good management conditions, which agrees with the high survival observed.

Specific growth rate indicates the daily increment in weight, being higher in fish fed at feeding rates of 2.5 and $4 \%$ biomass, irrespective of the feeding frequency. The supply of feed at the rate of $1 \%$ biomass was close to Rmain, which was $0.93 \%$. As the WG of fish from these treatments was close to zero, probably all the feed was consumed and used exclusively for the maintenance of vital activities. Accordingly, Barbosa et al. (2011) confirmed that the feeding rate of $1 \%$ biomass would not be sufficient to meet the nutritional requirements and energy demands of $C$. parallelus. The SGR of fish from treatments F4R4 and F6R4 were twice higher than all fish fed at 1\% biomass

The $C$. undecimalis juveniles exhibited the highest feed intake in the first meal of the day and the intake tended to decrease during the day. This observation differs from that reported by García-Galano et al. (2003), who found a higher feed intake in the evening. This apparent discrepancy is probably related to the initial size of the common snook, as García-Galano et al. (2003) used fish with an initial weight of about $30 \mathrm{~g}$. Another possible explanation for this discrepancy may be related to the differences in the daily temperature variation. In the study of García-Galano et al. (2003), water temperature increased from $26.1^{\circ} \mathrm{C}$ at $8: 30 \mathrm{~h}$ to $30.2^{\circ} \mathrm{C}$ at $18: 00 \mathrm{~h}$, while in our study, it remained constant throughout the day (means of $30.4,30.3,30.3$, and $30.3^{\circ} \mathrm{C}$ at 8:00, 11:00, 14:00, and 17:00 $\mathrm{h}$, respectively). Thus, there is an increased feed intake in higher temperatures as long as it remains within the optimum range for the species (Glencross, 2008; Bermudes et al., 2010; Cerqueira, 2010; Oliveira et al., 2013). As a result, fish reared at higher temperatures usually present higher feed efficiency and weight gain (Bendhack et al., 2013). These authors, for example, observed that $C$. parallelus reared at $29^{\circ} \mathrm{C}$ grew approximately eight times more than those at $20^{\circ} \mathrm{C}$.

From the above-mentioned, it is obvious that water temperature plays a primary role in defining the growth potential of common snook. Other external factors, however, also have an enormous effect on fish performance. For instance, the rearing volume has been shown to affect the growth performance and feed conversion of the European sea bass (D. labrax) (Samaras et al., 2017). Therefore, under rearing conditions that differ to the ones applied in the present study, the feeding rate and frequency recommended to common snook ( $C$. undecimalis) juveniles may need to be adjusted accordingly.

\section{Conclusions}

Common snook ( $C$. undecimalis) weighing between 1 and $16 \mathrm{~g}$ should be fed four to six meals a day at a daily feeding rate between 3.31 and $1.86 \%$, which should decrease as fish gain weight.

\section{Acknowledgments}

We are thankful to Prof. Dr. Vinicius Cerqueira and Caio Magnotti (Laboratory of Marine Fish Culture, UFSC, Brazil), for providing the fish used in this study. Funding from the Conselho Nacional de Desenvolvimento Científico e Tecnológico (CNPq) is gratefully acknowledged (Grants 308139/2012-7 and 406844/2012-7). The Fundação de Amparo à Ciência e Tecnologia de Pernambuco (FACEPE) granted a doctoral scholarship to R.L.M. Oliveira (IBPG - 0548-5.06/11). R.O. Cavalli is a research fellow of CNPq (307528/2017-0).

R. Bras. Zootec., 48:e20170292, 2019 


\section{References}

Alvarez-Lajonchère, L. S. 2004. Cultivo de robalos: Potencialidades e resultados. Panorama da Aquicultura 14:15-21.

Alvarez-Lajonchère, L. and Tsuzuki, M. Y. 2008. A review of methods for Centropomus spp. (snooks) aquaculture and recommendations for the establishment of their culture in Latin America. Aquaculture Research 39:684-700. https://doi.org/10.1111/j.1365-2109.2008.01921.x

Azzaydi, M.; Madrid, J. A.; Zamora, S.; Sanchez-Vazquez, F. J. and Martinez, F. J. 1998. Effect of three feeding strategies (automatic, ad libitum demand-feeding and time-restricted demand-feeding) on feeding rhythms and growth in European sea bass (Dicentrarchus labrax L.). Aquaculture 163:285-296. https://doi.org/10.1016/S0044-8486(98)00238-5

Barbosa, M. C.; Jatobá, A.; Vieira, F. N.; Silva, B. C.; Mouriño, J. L. P.; Andreatta, E. R.; Seiffert, W. Q. and Cerqueira, V. R. 2011. Cultivation of juvenile fat snook (Centropomus parallelus Poey, 1860) fed probiotic in laboratory conditions. Brazilian Archives of Biology and Technology 54:795-801. https://doi.org/10.1590/S1516-89132011000400020

Bendhack, F.; Peczek, V.; Gonçalves, R. and Baldan, A. P. 2013. Desempenho do robalo-peva em diferentes temperaturas de cultivo. Pesquisa Agropecuária Brasileira 48:1128-1131. https://doi.org/10.1590/S0100-204X2013000800046

Bermudes, M.; Glencross, B.; Austen, K. and Hawkins, W. 2010. The effects of temperature and size on the growth, energy budget and waste outputs of barramundi (Lates calcarifer). Aquaculture 306:160-166. https://doi.org/10.1016/j. aquaculture.2010.05.031

Biswas, G.; Thirunavukkarasu A. R.; Sundaray, J. K. and Kailasam, M. 2010. Optimization of feeding frequency of Asian seabass (Lates calcarifer) fry reared in net cages under brackishwater environment. Aquaculture 305:26-31. https://doi.org/10.1016/j.aquaculture.2010.04.002

Brett, J. R. 1979. Environmental factors and growth. p.599-675. In: Fish physiology. Hoar, W. S. and Randall, D. J., eds. Academic Press, New York.

CEAGESP - Companhia de Entrepostos e Armazéns Gerais de São Paulo. 2016. Cotações de preços no atacado. Available at: <http://www.ceagesp.gov.br/cotações>. Accessed on: Nov. 22, 2016.

Cerqueira, V. R. 2010. Cultivo de robalo-peva, Centropomus parallelus. p.489-520. In: Espécies nativas para piscicultura no Brasil. 2.ed. Baldisserotto, B. and Gomes, L. C., eds. Editora da UFSM, Santa Maria.

Cerqueira, V. R. and Tsuzuki, M. Y. 2009. A review of spawning induction, larviculture, and juvenile rearing of the fat snook, Centropomus parallelus. Fish Physiology and Biochemistry 35:17-28. https://doi.org/10.1007/s10695-008-9245-y

Cho, S. H.; Lee, S.-M.; Park, B. H.; Ji, S. C.; Choi, C. Y.; Lee, J. H.; Kim, Y. C.; Lee, J. H. and Oh, S. Y. 2007. Effect of daily feeding ration on growth and body composition of subadult Olive Flounder, Paralichthys olivaceus, fed an extruded diet during the summer season. Journal of the World Aquaculture Society 38:68-73. https://doi.org/10.1111/j.1749-7345.2006.00074.x

Corrêa, C. F. and Cerqueira, V. R. 2007. Effects of stocking density and size distribution on growth, survival and cannibalism in juvenile fat snook (Centropomus parallelus Poey). Aquaculture Research 38:1627-1634. https://doi.org/10.1111/ j.1365-2109.2007.01823.x

Corrêa, C. F. and Cerqueira, V. R. 2008. Densidade de estocagem para juvenis de robalo-peva após a larvicultura. Boletim do Instituto de Pesca 34:571-576.

Corrêa, C. F.; Leonardo, A. F. G.; Tachibana, L. and Corrêa Junior, L. 2010. Frequência alimentar para juvenis de robalo-peva criados em água doce. Revista Acadêmica: Ciência Animal 8:429-436. https://doi.org/10.7213/cienciaanimal.v8i4.10994

Costa-Bomfim, C. N.; Pessoa, W. V. N.; Oliveira, R. L. M.; Farias, J. L.; Domingues, E. C.; Hamilton, S. and Cavalli, R. O. 2014. The effect of feeding frequency on growth performance of juvenile cobia, Rachycentron canadum (Linnaeus, 1766). Journal of Applied Ichthyology 30:135-139. https://doi.org/10.1111/jai.12339

Dwyer, K. S.; Brown, J. A. and Parrish, C. 2002. Feeding frequency affects food consumption, feeding pattern and growth of juvenile yellowtail flounder, Limanda ferruginea. Aquaculture 213:279-292. https://doi.org/10.1016/S00448486(02)00224-7

Eroldoğan, O. T.; Kumlu, M. and Aktaș, M. 2004. Optimum feeding rates for European sea bass Dicentrarchus labrax L. reared in seawater and freshwater. Aquaculture 231:501-515. https://doi.org/10.1016/j.aquaculture.2003.10.020

Figueiredo, J. L. and Menezes, N. A. 1980. Manual de peixes marinhos do Sudeste do Brasil: III, Teleostei (2). Museu de Zoologia da Universidade de São Paulo, São Paulo, Brazil.

García-Galano, T.; Pérez, J. C.; Gaxiola, G. and Sánchez, A. 2003. Effect of feeding frequency on food intake, gastric evacuation and growth in juvenile snook, Centropomus undecimalis (Bloch). Revista de Investigaciones Marinas 24:145-154.

Glencross, B. D. 2008. A factorial growth and feed utilization model for barramundi, Lates calcarifer based on Australian production conditions. Aquaculture Nutrition 14:360-373.

Goddard, S. 1996. Feed management in intensive aquaculture. Chapman and Hall, Newfoundland.

R. Bras. Zootec., 48:e20170292, 2019 
Guroy, D.; Deveciler, E.; Kut Guroy, B. and Tekinay, A. A. 2006. Influence of feeding frequency on feed intake, growth performance and nutrient utilization in European sea bass (Dicentrarchus labrax) fed pelleted or extruded diets. Turkish Journal of Veterinary and Animal Science 30:171-177.

Harpaz, S.; Hakim, Y.; Barki, A.; Karplus, I.; Slosman, T. and Eroldogan, O. T. 2005. Effects of different feeding levels during day and/or night on growth and brush-border enzyme activity in juvenile Lates calcarifer reared in freshwater re-circulating tanks. Aquaculture 248:325-335. https://doi.org/10.1016/j.aquaculture.2005.04.033

Kim, K. D.; Kang, Y. J.; Kim, K. W. and Kim, K. M. 2007. Effects of feeding rate on growth and body composition of juvenile flounder, Paralichthys olivaceus. Journal of the World Aquaculture Society 38:169-173. https://doi.org/10.1111/j.17497345.2006.00086.x

Kubitza, F. and Lovshin, L. L. 1999. Formulated diets, feeding strategies, and cannibalism control during intensive culture of juvenile carnivorous fishes. Reviews in Fisheries Science 7:1-22. https://doi.org/10.1080/10641269991319171

Lima-Junior, S. E.; Cardone, I. B. and Goitein, R. 2002. Determination of a method for calculation of allometric condition factor of fish. Acta Scientiarum 24:397-400.

Oliveira, L. A. A. G.; Almeida, A. M.; Pandolfo, P. S. V.; Souza, R. M.; Fernandes, L. F. L. and Gomes, L. C. 2013. Crescimento e produtividade de juvenis de robalo-peva a diferentes temperaturas e taxas de alimentação. Pesquisa Agropecuária Brasileira 48:857-862. https://doi.org/10.1590/S0100-204X2013000800007

Ribeiro, F. F.; Forsythe, S. and Qin, J. G. 2015. Dynamics of intracohort cannibalism and size heterogeneity in juvenile barramundi (Lates calcarifer) at different stocking densities and feeding frequencies. Aquaculture 444:55-61. https://doi.org/10.1016/j.aquaculture.2015.03.029

Rivas, L. R. 1986. Systematic review of the perciform fishes of the genus Centropomus. Copeia 1986:579-611.

Salama, A. J. 2008. Effects of different feeding frequency on the growth, survival and feed conversion ratio of the Asian sea bass Lates calcarifer juveniles reared under hypersaline seawater of the Red Sea. Aquaculture Research 39:561-567. https://doi.org/10.1111/j.1365-2109.2007.01890.x

Samaras, A.; Pavlidis, M.; Lika, K.; Theodoridi, A. and Papandroulakis, N. 2017. Scale matters: performance of European sea bass, Dicentrarchus labrax, L. (1758), reared in cages of different volumes. Aquaculture Research 48:990-1005. https://doi.org/10.1111/are.12942

Sanches, E. G.; Silva, F. C. and Ramos, A. P. F. D. 2014. Viabilidade econômica do cultivo do robalo-flecha em empreendimentos de carcinicultura no nordeste do Brasil. Boletim do Instituto de Pesca 40:577-588.

Shearer, K. D. 2000. Experimental design, statistical analysis and modeling of dietary nutrient requirement studies for fish: a critical review. Aquaculture Nutrition 6:91-102. https://doi.org/10.1046/j.1365-2095.2000.00134.x

Tsuzuki, M. Y. and Berestinas, A. C. 2008. Desempenho de juvenis de robalo-peva Centropomus parallelus com diferentes dietas comerciais e frequências alimentares. Boletim do Instituto de Pesca 34:535-541.

Tsuzuki, M. Y.; Cardoso, R. F. and Cerqueira, V. R. 2008. Growth of juvenile fat snook Centropomus parallelus in cages at three stocking densities. Boletim do Instituto de Pesca 34:319-324.

Tsuzuki, M. Y.; Guarizi, J. D.; Annunciação, W. F. and Sorandra, C. 2014. Frequência alimentar e densidade de estocagem para juvenis de robalo-peva em tanques-rede. Boletim do Instituto de Pesca 40:629-637.

Tucker, J. W. 1987. Snook and tarpon snook culture and preliminary evaluation for commercial farming. The Progressive Fish-Culturist 49:49-57. https://doi.org/10.1577/1548-8640(1987)49\%3C49:SATSCA\%3E2.0.CO;2

Tucker, J. W. 2000. Marine fish culture. Kluwer Academic Publishers, Massachusetts.

Türkmen, S.; Eroldoğan, O. T.; Yilmaz, H. A.; Ölçülü, A.; Inan, G. A. K.; Erçen, Z. and Tekelioğlu, N. 2012. Compensatory growth response of European sea bass (Dicentrarchus labrax L.) under cycled starvation and restricted feeding rate. Aquaculture Research 43:1643-1650. https://doi.org/10.1111/j.1365-2109.2011.02970.x

Xie, F.; Ai, Q.; Mai, K.; Xu, W. and Ma, H. 2011. The optimal feeding frequency of large yellow croaker (Pseudosciaena crocea Richardson) larvae. Aquaculture 311:162-167. https://doi.org/10.1016/j.aquaculture.2010.12.005 